\title{
Síndrome de Gorlin-Goltz: serie de 7 casos
}

\author{
Gorlin-Goltz Syndrome. A 7 cases serie.
}

El síndrome del nevus basocelular (SNBC) o síndrome de Gorlin Goltz es una rara entidad autosómica dominante con penetrancia completa pero expresividad variable, que se caracteriza fenotípicamente por la presencia de anomalías en el desarrollo y tumores postnatales. Las alteraciones consideradas tradicionalmente más características del síndrome son la presencia de epiteliomas o carcinomas basocelulares. queratoquistes múltiples mandibulares y pits palmo-plantares. Otros tumores asociados en mucho menor porcentaje son los meduloblastomas y meningiomas además de diversas alteraciones esqueléticas. El SNBC está causado por mutaciones en el gen supresor PATCHED1 (PTCH 1) que es el gen humano homólogo al gen patched de la Drosophila y que mapea en el chromosoma 9 q22.3. Hasta un $50 \%$ de los casos son provocados por nuevas mutaciones.

Los autores, en la serie que publican recogen 7 casos de este raro síndrome y describen sus características clínicas y manejo terapéutico. Se trata de una entidad que al presentar múltiples patologías afectando a diversos órganos debe ser manejada de forma multidisciplinar (cirujanos maxilofaciales, dermatólogos, traumatólogos, etc.).

Los carcinomas basocelulares, como ocurre en la serie presentada, son la manifestación clínica más frecuente, prácticamente el $100 \%$ de los pacientes lo desarrollarán a lo largo de su vida. Son tumores que aparecen de forma precoz (generalmente antes de los 20-30 años) y de forma múltiple y progresiva. Afectan con más frecuencia a las zonas expuestas a la radiación ultravioleta (cabeza y cuello) y son más frecuentes en pacientes con fototipos bajos (pieles claras). Clínicamente muchas de estas lesiones son eritematosas de pequeño tamaño confundiéndose con lesiones névicas, de ahí el nombre que se dio a la entidad de síndrome de nevus basocelular. La prevalencia de estos tumores es mayor en la raza caucásica que en el resto. En poblaciones asiáticas se han descrito con una incidencia mucho menor.

El tratamiento de los carcinomas basocelulares puede realizarse con métodos quirúrgicos y no quirúrgicos. Se ha utilizado cirugía, curetaje, electrocoagulación, cirugía micrográfica de Mohs, laserterapia, 5-fluorouracilo, imiquimod, terapia fotodinámica y radioterapia. Siempre debemos utilizar el método que cause la mínima morbilidad debido a la multiplicidad de las lesiones y su aparición progresiva con la máxima eficacia. Estamos de acuerdo con los autores en que la exéresis quirúrgica es una de las principales opciones terapéuticas de estos tumores. La terapia fotodinámica, que consiste en la aplicación tópica de un fotosensibilizante (ac. metil levulínico u otros) y la irradiación posterior de la zona con una luz específica $(630 \mathrm{~nm})$, permite el tratamiento de múltiples carcinomas basocelulares en una misma sesión evitando cicatrices inestéticas y con altas tasas de eficacia. Esta terapia constituye hoy día
The nevoid basal cell carcinoma syndrome (NBCCS) or Gorlin-Goltz Syndrome is a rare autosomal dominant disorder with complete penetrance but variable expressivity. Its phenotype is characterized by the presence of anomalies in development and postnatal tumors. The alterations that are considered traditionally characteristic of the syndrome are the presence of epitheliomas or basal cell carcinomas, multiple mandible keratocysts and palmar and plantar pits. In addition to the diverse skeletal alterations, medulloblastomas and meningiomas are tumors that are associated in a much smaller percentage. NBCCS is caused by mutations in the suppressor gene PATCHED1 (PTCH 1) which is the human gene homologous human to the PATCHED gene of the Drosophila that maps the arm $9 q$ chromosome. As many as $50 \%$ of the cases are caused by new mutations.

The authors collect 7 cases of this rare syndrome and describe their clinical characteristics and therapeutic treatment. It deals with an entity whose pathologies affect multiple organs and therefore should be handled in a multidisciplinary fashion (maxillofacial surgeons, dermatologists, traumatologists, etc.).

Basal cell carcinomas, as we see in this series, are the most common clinical manifestation. Practically $100 \%$ of patients develop them throughout their life. They are tumors that appear early in life (generally between the ages of 2030), are progressive and multiple tumors appear at the same time. They tend to appear in areas that are exposed to ultraviolet radiation (head and neck) and are more common in patients with light skin types (fair skin). Many of these small lesions are erthematous and are often clinically confused with "nevica" lesions, which is where the name nevoid basal cell comes from. These tumors are most prevalent in Caucasians. In Asian populations they are much less frequent.

Basal cell carcinomas treatment can include surgical and non surgical methods. Methods used include: surgery, curettage, electro coagulation, micrographic Mohs surgery, laser therapy, 5 flourouracilo, imiquimod, photodynamic therapy and radiotherapy. We should always choose the method with the lowest morbidity and maximum effectiveness because the lesions are progressive multiple. We agree with the authors that surgical abscission is one of the principle treatment options for these tumors. Photodynamic therapy consists of topical application of photosensitive (levulinic methyl and others) and posterior radiation of the area with a specific light $(630 \mathrm{~mm})$. This allows for the treatment of multiple basal cell carcinomas in the same session which avoids unpleasant scarring and has high success rates. This ther- 
una opción de primera línea en estos pacientes, fundamentalmente en carcinomas superficiales y multicéntricos (los más frecuentes en estos pacientes). Otro de los tratamientos de elección en carcinomas basocelulares de tipo superficial o multicéntrico es el empleo de imiquimod al 5\% de forma tópica. Es un tratamiento que se realiza de forma ambulatoria con altas tasas de eficacia y con mínima morbilidad (sin dejar cicatrices) lo que contribuye a la cumplimentación por parte del paciente.

En el manejo de los carcinomas basocelulares en pacientes con SNBC es fundamental el diagnóstico precoz y las revisiones periódicas. Vamos a requerir múltiples tratamientos y es por esto que debemos implicar al paciente y consensuar el tratamiento más adecuado. Como refieren los autores, en pacientes con una alta tasa de carcinomas basocelulares se ha utilizado como tratamiento preventivo el uso de retinoides orales (acitretina). No obstante, debido a que las dosis requeridas para su eficacia son muy altas y causan importantes efectos adversos, su uso hoy día es muy limitado. La medida preventiva fundamental en estos pacientes es evitar la exposición a la luz solar, a la radiación ultravioleta y utilizar fotoprotectores adecuados. Por otra parte debe evitarse el uso de radioterapia en el tratamiento de las neoplasias de estos pacientes siempre que sea posible por el efecto favorecedor y multiplicador de la aparición de carcinomas basocelulares en pacientes con SNBC.

Los pits palmo-plantares es la segunda manifestación cutánea más prevalente en pacientes con SNBC. Se trata de pequeños defectos en el estrato córneo que se manifiestan por pequeñas zonas puntiformes hiperqueratósicas. Son lesiones benignas que no requieren tratamiento salvo que sean sintomáticas. Su presencia es un buen marcador de la enfermedad, si bien pueden aparecer también en personas expuestas de forma crónica a arsénico y en otras patologías.

Los queratoquistes mandibulares o maxilares con frecuencia son la primera manifestación clínica del SNBC. Suelen ser lesiones inicialmente asintomáticas que se diagnostican radiológicamente y que requieren un abordaje quirúrgico específico.

El diagnóstico del SNBC se basa en la presencia simultánea y de forma precoz de anomalías que no son específicas de los pacientes con SNBC. La intensidad y gravedad de las mismas es además variable en distintos pacientes con SNBC incluso dentro de una misma familia afecta, dependiendo de la expresividad genética y factores potenciadores. Es fundamental el conocimiento de todas las anomalías de esta entidad para poder realizar un diagnóstico precoz y un seguimiento adecuado. Como señalan los autores en su artículo existen una serie de criterios mayores y menores que ayudan al diagnóstico. Hoy día la realización de tests genéticos y la determinación de mutaciones del gen PTCH1 permiten confirmar molecularmente el diagnóstico clínico, si bien su positividad no ocurre en todos los casos. Por último, en los pacientes afectos debe realizarse consejo genético. El 50\% de la descendencia de un paciente con SNBC desarrollará la enfermedad pudiéndose detectar de forma prenatal si el paciente lo desea. apy is a cutting edge option for these patients, especially in superficial and multicentric carcinomas (the most common among these patients). The superficial or multicentric topical use of 5\% imiquimod is another treatment option preferred for basal cell carcinomas. This is an out patient treatment with high success rates and low morbidity (does$n^{\prime} t$ leave scars) which contributes to patients fulfillment.

When handling basal cell carcinomas in patients with NBCSS early diagnosis and periodic reviews are very important. We are going to need multiple treatments and because of this it is important to involve the patient and agree on the most appropriate treatment. As the authors mention, patients for with high basal cell carcinoma rates oral retinoid was used as a preventative treatment. However, due to the fact that the doses needed to be effective is high and causes significant side effects, its use today is limited. The major preventative precaution is to avoid exposure to sunlight, ultraviolet rays and to use adequate sunscreen. It is also recommended that radiotherapy treatment be avoided when treating these patients for neoplasias because there is always the possibility that basal cell carcinomas appear as a possible side effect in NBCSS patients.

Palmar and plantar pits are the second most common cutaneous manifestation in NBCSS patients. They consist of small defects in the cornea layer and they form in small hyperkeratosic punctiform zones. They are benign lesions that don't need treatment unless they are symptomatic. Their presence is a good marker of the illness even though they can also appear in people who are at chronic risk of arsenic and other pathologies.

Mandible and Maxilla keratocysts are commonly the first clinical manifestation of NBCSS. They are usually asymptomatic lesions that are radio logically diagnosed and require specific surgical approach.

NBCSS diagnosis is based on the simultaneous and early presence of anomalies that are not specific to patients with NBCSS. The intensity and severity of these lesions is also variable for each patient who has NBCSS, even within the same affected family, depending on the genetic expression and potentiate factors. Knowledge of all of the anomalies of this entity is fundamental to being able to have an early diagnosis and adequate follow up. Like the authors mention in their article, there is a series of major and minor criteria that helps diagnosis. Today performing genetic tests and determining PTCH gene mutations allows us to confirm clinical diagnosis, even though it is not positive in all cases. Finally, affected patients should get genetic advice. $50 \%$ of descendents of a NBCSS patient will develop the illness and it can be prenatally detected if the patient wishes.
José Luis López-Estebaranz Dermatólogo Práctica privada. Madrid. España 


\section{Bibliografía}

1. Gorlin RJ. Nevoid basal cell carcinoma syndrome. Dermatol Clin 1995; 13:113-25.

2. Kimonis VE, Goldstein AM, Pastakia B, Yang ML, Kase R, y cols. Clinical manifestations in 105 persons with nevoid basal cell carcinoma syndrome. Am J Med Genet 1997;69:299-308.

3. Pruvost-Balland C, Gorry P, Boutet N, Magnaldo T, Mamelle G, y cols.
Clinical and genetic study in 22 patients with basal cell nevus syndrome. Ann Dermatol Venereol 2006;133:117-23.

4. Tanabe R, Fujii K, Miyashita T, Uchikawa H, Endo M, y cols. Clinical manifestations in 25 Japanese patients with Gorlin syndrome. No To Hattatsu 2009;41:253-7.

5. Van der Geer S, Ostertag JU, Krekels GA. Treatment of basal cell carcinomas in patients with nevoid basal cell carcinoma syndrome. I Eur Acad Dermatol Venereol 2009;23:308-13. 